Academic City University College - Accra Ghana

Society for Multidisciplinary \& Advanced Research Techniques (SMART) Africa

Tony Blair Institute for Global Change

FAIR Forward - Artificial Intelligence for All - Deutsche Gesellschaft für Internationale Zusammenarbeit (GIZ) GmbH

Accra Bespoke Multidisciplinary Innovations Conference (ABMIC)

\title{
Impact of Covid Pandemic on Teaching Effectiveness of History Teachers in Senior Secondary Schools, Ogun State.
}

\author{
Ajobiewe Jamiu Olatunji \\ Centre for General Studies \\ Ogun State Institute of Technology, \\ Igbesa, Ogun State \\ Email: Tunjiajobiewe@yahoo.com \\ Phone: +2348035690405
}




\title{
Impact of Covid Pandemic on Teaching Effectiveness of History Teachers in Senior Secondary Schools, Ogun State.
}

\author{
Taylor, O.E., Ezekiel, P.S. \& Emmah, v.T.
}

\begin{abstract}
The effect of the COVID-19 pandemic globally and the disruptions occasioned by it has farreaching implications on societies in general and most especially the educational sector. This study therefore investigates the impact of COVID-19 pandemic on teaching effectiveness of History teachers using Ado-Odo/Ota L.G.A of Ogun State, Nigeria as a case study. The study adopted descriptive survey research design, while simple random sampling was used to select a sample population of 40 participants (History teachers) with 2 History teachers selected from 20 selected public and private senior secondary schools. The questionnaire was administered to the participants which was collected immediately after administering them. The data collected from the respondents was used to answer the research questions posed in the studyusing descriptive statistics tools. The study found that History teachers from private senior secondary schools responded to virtual teaching than those from public senior secondary schools and that there is significant relationship between learning- from home and teaching effectiveness of History teachers. The study concludes that online education helps to keep the students up and running with an opportunity for self-study as well as improved teaching effectiveness of History teachers. The study recommends that relevant government agencies should ensure that national curriculum is adapted for the future in response to the current crisis to enable more effective teaching on e-learning. The researcher recommended that teachers and learners need training on ICTs and e-learning facilities as to how they can be used to support learning.
\end{abstract}

Keywords: History, Covid-19, pandemic, teaching effectiveness, students, Ogun State Information and Communication Technology (ICT), senior secondary school,

\section{BACKGROUND TO THE STUDY}

COVID-19, a novel disease, became recognized when it was identified as the causative agent in reported cases of patients with pneumonia admitted in hospitals in Wuhan, China, in late December 2019 (Munster et al. 2020; Zhu et al. 2020). COVID-19 transmits when people breathe in air contaminated by droplets and small airborne particles. The risk of breathing these in is highest when people are in close proximity, bust they can be inhaled over longer distances, particularly indoors (WHO Report, 2020). In March 12 2020, the WHO officially declared COVID19 also known as coronavirus a pandemic (WHO 2020). Due to this pandemic, educational institutions in most countries around the world were grounded and closed. This was buttressed by the data obtained from UNESCO which states that the peak in closure of schools all over the world was in April, 2020 when about 1.6 billion students were affected across 194 countries (UNESCO, 2020). Nigeria government was also so proactive early enough to close all Public schools in Nigeria including Private schools at all levels. 
As the COVID-19 Pandemic runs its course, many governments are implementing measures that limit the number of people congregating in public places. Such measures have disrupted the normal functioning of schools and universities. Because the duration of such measures has been extensive - and is likely to continue in some countries for a certain time until a vaccine becomes available - leaders of public and private education institutions put in place alternative methods for students and teachers to continue with their lessons when attending school is not possible and are working on methods that will make schools fit for working in a safe environment. Implicitly, Covid-19 has affected all of the education sectors: early childhood, primary, secondary, higher and vocational, and all have suffered because of the pandemic, each sector has suffered in different ways and with different consequences. It would be facile to say that secondary education suffered the least, because the students are youth, and they are much more likely to have access to the internet and digital technologies than others.

But it would be true to say that, without underestimating the challenges, it was only the private secondary schools that were proactive thoughtful enough to reduce the educational impact of Covid-19 on their studentsby employing the service of new educational technologies through internet using social media like facebook, Instagram, Google class, Zoom etc to teach and assess their students online. The government at a point started using state radio and television as a form of instructional strategies to teach their students during the pandemic.

The closure of schools meant that management of secondary had to come up with strategies that will ensure that learning continues during the lockdown. Some private secondary schools had to quickly move from traditional face-to-face teaching method to remote education in order to account for the school fees collected and still maintain appreciable number of students in their schools, they ensured that the students really learned through those media, hence maintained teaching effectiveness. The abrupt, unplanned, and rapid transition into online learning triggered by COVID 19 has contributed to cognitive dissonance because our educational expectations are called into question.

Teacher effectiveness is generally referred to in terms of the focus on students, their performance, teacher behaviours, the classroom procedures and conduct that are implemented in order to better the outcomes of the students. Teacher effectiveness besides focusing upon the performance of the students centers on the number of areas; effective teachers have to be clear about the instructional goals, possess sufficient knowledge about the content of the curriculum and the strategies for teaching, communicating appropriately with the students of what is expected of them, following appropriate teaching techniques and material to make learning useful, should be knowledgeable and aware about the students, adapting instruction to their requirements, anticipating misapprehensions in their existing knowledge, teaching students meta-cognitive strategies and providing them with opportunities to master them, addressing higher as well as lower level cognitive objectives, monitoring the understanding and performance of the students by providing feedback, integrating their instruction with that in other subject areas, and accepting responsibility for student's outcomes (Ko, Summons \&Bakkum, 2013).

All these became more challenging when considering History subject that are often seen as difficult for students due to different factors like too voluminous and too complex to understand for an ordinary students. This made the teaching effectiveness questionable during the pandemic as a result of change in instructional materials as well as instructional strategies from traditional lecture method of face-to-face to online learning. 
According to Hammond, 2010, teacher effectiveness centers on good teaching, possessing appropriate and sufficient knowledge of the subject matter, evaluating the students, identifying their appropriate learning needs and requirements, possessing skills regarding the usage of instructional material and strategies to engage and challenge the students, but unfortunately many of History teachers lack the requisite skills in Information and Communication Technology tools that will guarantee effective teaching.

While the need for distance learning was clear from the outset of the pandemic, achieving effective reach to students was more complex. Secondary schools were left to their own devices and their responses varied according to their resources and resourcefulness. But, for the majority, neither students nor teachers had any prior experience in teaching and learning outside the classroom. Government responses varied: many provided television and radio educational programmes, sometimes in partnership with the private sector, but not all were well organised. Some countries undertook effective interventions, others did not. This did not always equate to their relative wealth or poverty. It was quickly clear that, for the majority of learners, sophisticated technological approaches were not always the answer to teaching effectiveness. To this end, this study examines the effects of COVID-19 on teaching effectiveness in History using some selected public and private secondary schools in Ado-Odo/Ota Local Government Area of Ogun State as a case study.

\subsection{Statement of the Problem}

The COVID-19 pandemic presents unique challenges for Nigeria's already fragile education system (Obiakor\&Adeniran, 2020). Before the pandemic, there was an estimated total of 10.2 million out-of-school children. In response to this education emergency, the federal and state governments and private sector are implementing various learning interventions using technological platforms, internet-based tools and traditional media to mitigate the impact of the closure of schools. With the increasing adoption of remote learning interventions, there is limited evidence of their effectiveness. Given that many of these interventions have been adopted as immediate responses to the crisis (without prior large-scale implementation), it is important to interrogate if and how they are working. It is also imperative to generate data that can strengthen the decision-making power of key stakeholders within the Nigerian education landscape, during and post-COVID-19.

In light of this, this study examines education interventions that are being implemented in Nigeria during the COVID-19 pandemic by History teachers that contributes to knowledge on education provision in emergency contexts and guarantee teaching effectiveness. On school management side, this study seeks to understand the nature of the response; who is doing what, how they are implementing interventions, the extent of their reach, and the resultsor effects of the interventions being delivered. On the learners' side, this study seeks to understand what students are learning, how they are accessing the learning opportunities, the pros and cons of the adapted ways of learning, and the resources they need to accesslearning at this time. 


\subsection{Objective of the Study}

The overall objective of the study was to examine the effects of COVID-19 on teaching effectiveness of Historyteachers.

The specifically the study sought to:

i. examine the immediate impact of the COVID-19 pandemic on students' learning of History in some selected secondary schools in Ado Odo/OtaLocal Government Area of Ogun State;

ii. investigate the innovations that are aiding of History teachers during the COVID-19 pandemic?

iii. assess the impact of COVID-19 on teaching effectiveness of History teachers in some selected secondary schools in Ado Odo/Ota Local Government Area of Ogun state and

iv. elucidatethe implications of learning- from home on teaching effectiveness of History teachers in some selected secondary schools in Ado Odo/Ota Local Government Area of Ogun State?

\subsection{Research Questions}

The following research questions guided the study:

1. What is the immediate impact of the COVID-19 pandemic on students' learning in Nigeria?

2. What are the innovations that are aiding teaching effectiveness of History teachers during the COVID-19 pandemic?

3. Is there any impact of COVID-19 on teaching effectiveness of Historyteachers in the selected secondary schools in Ado Odo/Ota Local Government Area of Ogun State?

4. What are the implications of learning- from home on teaching effectiveness of History teachers in someselected secondary schools in Ado Odo/Ota Local Government Area of Ogun State?

\subsection{Research Hypotheses:}

The following null hypotheses were tested by the study at 0.05 level of significance.

$\mathrm{H}_{01}$ : There is no significant impact of the COVID-19 pandemic on students' learning in Nigeria?

$\mathrm{H}_{0}$ 2: There are no significant innovations that are aiding teaching effectiveness of History teachers during the COVID-19 pandemic.

Ho3: There is no significant impact of COVID-19 on teaching effectiveness of History teachers in the selected secondary schools in Ado Odo/Ota Local Government Area of Ogun State.

$\mathrm{H}_{0} 4$ : There are no significant implications of learning- from home on teaching effectiveness of History teachers in the selected secondary schools in Ado Odo/Ota Local Government Area of Ogun State.

\section{OVERVIEW OF COVID-19 IN NIGERIA}

pandemic caused by severe acute respiratory syndrome coronavirus 2 (SAR COV-2) (Marra, 2003 \& Butterfield, 2013). Coronaviruses are common in certain species of animals, such as cattle camels and bats which can be transmitted to humans. Some health experts believe that the new strain of coronavirus likely originated in bats or pangolins (Anthony, 2017). The first transmission to humans was in Wuhan, China (Hui, 2020 \& Chin, 2020). Since then, the virus has mostly spread through person-to-person contact. The most common way that this virus spreads is through close contact with already infected person. 
When people with COVID-19 breathe out or cough, they expel tiny droplets that contain the virus. These droplets can enter the mouth or nose of someone without the virus, causing the spread of infection to occur (Parry, 2020). The disease is most contagious when a person's symptoms are at their peak though, it is possible for someone without symptoms to spread the virus (Landry, 2020). Droplets containing the virus can also land on nearby surfaces or objects and when other people touch such surfaces or pick up the objects and then touches their nose, eyes, or mouth the virus spreads (Parry, 2020 \& Landry, 2020).

The first case of COVID-19 was reported in Nigeria by the Federal Ministry of Health on 27th February, 2020. This was the case of an Italian citizen who works in Nigeria and returned from Milan, Italy to Lagos, Nigeria on the 25th of February, 2020 (Maclean \&Dahir, 2020). Since then, the number of confirmed cases of infection keep rising both in Nigeria and across the globe. Nigeria placed a travel ban on 13 countries with high cases of the virus, the countries are; United States, United Kingdom, South Korea, Switzerland, Germany, France, Italy, China, Spain, Netherland, Norway, Japan and Iran. On 11th March 2020, World Health Organization (WHO) declares COVID-19 a pandemic. A pandemic is a disease that has spread across a large region; for instance, multiple continents or worldwide (Cucinotta\&Vanelli, 2020).

The Covid-19 pandemic arrived in Africa at a time of growing optimism about the continent's future prospects. Many African economies had been enjoying sustained periods of growth at rates that were envied by countries in Europe, North America and even in Asia and the Pacific. There were ambitious plans to build on these promising foundations and 54 African countries had committed themselves to create the world's largest common free trade area - the African Continental Free Trade Area (AfCFTA). The African Union had set out a comprehensive vision for the future, Agenda 2063, which aimed to provide "a blueprint and master plan for transforming Africa into the global powerhouse of the future," entrenching sustainable growth and consigning poverty, conflict and disease to the past. At the heart of the plan was education and the desire for a "skills revolution underpinned by science, technology and innovation." ("Education is Crucial to Africa's Covid-19 Response,' Bernard, Coulibaly and Winthrop, Brookings Institution, 4 June 2020).

\section{RESEARCH METHODOLOGY}

This study aims to investigate the effect of COVID-19 on teaching effectiveness of History teachers using some selected secondary schools (both Public and Private) in Ado Odo/Ota Local Government Area as a case study. The central focus of this study is to determine whether there is a gap in teaching effectiveness of History teachers before and during COVID-19 pandemic.

A descriptive survey research design was used to carry out this study. Besides, this study also investigates the innovations that are aiding teaching effectiveness of History teachers during the COVID-19 pandemicin some selected secondary schools in Ado Odo/Ota Local Government Area of Ogun State. The population surveyed consists of History teachers in some selected secondary schools in Ado Odo/Ota Local Government Area of Lagos State. The study was conducted in twenty (20) selected secondary schools (both public and private secondary schools)in Ado Odo/Ota Local Government Area of Ogun State of Nigeria. The random sampling techniques was used to select twenty (20) selected secondary schools (both public and private secondary schools) in Ado Odo/Ota Local Government Area of Ogun State of Nigeria. Total number of 2 respondents each per secondary school were randomly selected making the total of 40 selected teachers for the study. 
A questionnaire developed by the researchers was used for the purpose of the study. The instrument showed good measures of internal consistency, with a Cronbach's alpha value of 0.962. 20 questions were raised which according to their content relate to the stated objectives. The questionnaire consisted of two parts. The first part of questionnaire covered basic demographic information. The second part consisted of 20 questions for the self-assessment of the respondents in order to elicit their opinions. These questions were rated on a four Likert scale as follows:

Strongly agree $=(S A)$, Agree $=(A)$, Disagree $=(D A)$ and Strongly Disagree $(S D)$.

The data collected for the study was analyzed using both qualitative and quantitative methods. According to Patton (1990), the analysis of the empirical data aims to make sense of massive amount of data, reduce the volume of information, identify significance patterns and construct a framework for communicating the essence of data revealed. Descriptive statistics such as frequencies and simple percentages were used in calculating the demographic characteristics of the respondents. The responses of the respondents on each research questions were summed up and the total frequencies were used to determine the mean score and standard deviation for each item. A cut off point was determined by finding the mean of the values assigned to the options using the formula below:

$X=\frac{\Sigma X}{N}$

$\Sigma=$ Summation $X=$ Nominal values of options

$\mathrm{X}=$ MeanN $=$ Numbers of items

In order to determine the cutoff point on the criterion level, the following measure was established:

Table 1:Determination of the cut off point for mean score

\begin{tabular}{lccc}
\hline & Scaling statement & Values \\
Highly Effective $(\mathrm{HE})$ & Strongly Agree & SA & 4 \\
Effective $(\mathrm{E})$ & Agree & A & 3 \\
Ineffective $(\mathrm{I})$ & Disagree & D & 2 \\
Highly Ineffective $(\mathrm{HI})$ & Strongly Disagree & SD & 1 \\
\hline
\end{tabular}

Table1 above sh̄ows that: $\quad N=4, \quad X=\frac{10}{4} \quad X=2.5$

Table 2 Distribution of Respondents by Sex

\begin{tabular}{|l|c|c|}
\hline Sex & Frequency & Percentage (\%) \\
\hline Male & 12 & 30 \\
\hline Female & 28 & 70 \\
\hline Total & 40 & 100 \\
\hline
\end{tabular}

Source: Field survey, 2021

The respondents were asked to indicate their gender. It turned out that $29(43.28 \%)$ of the teachers were male while 38 (56.72\%) were female as observed in Table 2 Research by Davidson et al. (2005) showed that female / male composition of teaching and senior posts is not new; the majority of teachers in England are women yet relatively there are a greater proportion of male teachers in senior positions. 
From the findings of the study, it can be said that there are more femaleHistory teachers than male Historyteachers in Secondary schools with the study area.

Table 3: Distribution of Respondents by Age

\begin{tabular}{|l|l|l|}
\hline Age & Frequency & Percentage (\%) \\
\hline $20-29$ years & 4 & 10 \\
\hline $20-39$ years & 19 & 47.5 \\
\hline $40-49$ years & 10 & 25 \\
\hline $50-59$ years & 7 & 17.5 \\
\hline Total & 40 & 100 \\
\hline
\end{tabular}

Source: Field survey, 2021

Table 3 reveals that $7(17.5 \%)$ of the teachers were between 50-59years, 10 (25\%) were between 40-49 years, 19 (47.5\%) were between 30-39years and 4(10\%) were between 20-29 years old. Majority (47.5\%) of the Historyteachers in Ado Odo/Ota Local Government of Ogun State is between $40-49$ years.

A study in Tanzania by Bennell and Mukyanuzi (2005) on teachers'effectiveness crisis, they found that individual teacher characteristics can also adversely impact on level of effectiveness. They added that age profile of teachers has become younger in many countries due to the rapid expansion of primary and, more recently, secondary school enrolments and/or higher rates of teacher attrition.

Table 4: Distribution of Respondents by Marital Status

\begin{tabular}{|l|l|l|}
\hline Marital Status & Frequency & Percentage (\%) \\
\hline Single & 10 & 25 \\
\hline Married & 29 & 72.5 \\
\hline Widow & 1 & 2.5 \\
\hline Total & 40 & 100 \\
\hline
\end{tabular}

Source: Field survey, 2021

The table 4 above shows respondents distribution on the basis of marital status. Descriptive statistics revealed that 10 (25\%) were single, 29 (72.5\%) were married and 1 (2.5) was a widow. This means that there are more married than single Historyteachers in Senior Secondary schools in Ado Odo/Ota Local Government Area of Ogun State of Nigeria. This positively impacts teachers' effectiveness due to some benefits derived from marital experience.

Table 5: Distribution of Respondents by Teaching Experience

\begin{tabular}{|l|l|l|}
\hline Teaching Experience & Frequency & Percentage (\%) \\
\hline Less than 5 years & 8 & 20 \\
\hline $5-10$ years & 15 & 37.5 \\
\hline $11-20$ years & 10 & 25 \\
\hline $21-30$ years & 7 & 17.5 \\
\hline Total & \multicolumn{1}{|c|}{40} & 100 \\
\hline
\end{tabular}

Source: Field survey, 2021 
The Table 5 consists of teaching experience of teachers. They were asked to indicate the period for which they had taught in the school. It turned out that $8(20 \%)$ of the respondents indicated that they had taught for a period less than 5years, 15 (37.5\%) of the respondents had taught for a period between 5 - 10 years, 10 (25\%) had taught for a period between 11 - 20 years and $7(17.5 \%)$ had taught for a period of $21-30$ years. From the findings of the study, it can be said that majority of teachers had taught for a long period of time, they possessed through their years of experience the requisite for effective teaching but by other factors which were the interest of this study.

Table 6: Distribution of Respondents by Academic Qualification

\begin{tabular}{|c|l|l|}
\hline Academic Qualification & Frequency & Percentage (\%) \\
\hline HND & 2 & 5 \\
\hline B. Ed & 30 & 75 \\
\hline M. Ed & 8 & 20 \\
\hline Total & 40 & 100 \\
\hline
\end{tabular}

Source: Field survey, 2021

The teachers (respondents) were asked to indicate their highest academic qualifications. It turned out that 2 (5\%) had Higher national Diploma, that 30 (75\%) had Bachelor's Degree in education, 8 (20\%) respondents had Master's degree in education, From the findings of the study, it can be said that most teachers in Senior secondary schools in Ado Odo/Ota Local Government Area of Ogun State were qualified academically and professionally.

\section{ANALYSIS OF RESEARCH QUESTIONS}

Research Question 1

What is the immediate impact of the COVID-19 pandemic on students' learning in Nigeria? The research question was answered using the data presented in Table 7.

Table 7

\begin{tabular}{|c|c|c|c|c|}
\hline $\mathrm{S} / \mathrm{N}$ & $\begin{array}{l}\text { Mean ratings of respondents on the impact of } \\
\text { the COVID-19 pandemic on students' learning }\end{array}$ & $\begin{array}{l}\text { X } \\
\text { Mean of } \\
\text { History } \\
\text { Teachers }\end{array}$ & $\begin{array}{l}\text { SD } \\
\text { Standard } \\
\text { Deviation }\end{array}$ & Remarks \\
\hline 7 & $\begin{array}{l}\text { Speed and cost of internet hinder me from } \\
\text { proper delivery of study materials }\end{array}$ & 2.55 & 5.67 & Agreed \\
\hline 8 & $\begin{array}{l}\text { There is always internet failure on my laptop } \\
\text { which caused loss of interest. }\end{array}$ & 2.03 & 4.5 & Disagreed \\
\hline 9 & It is hard to teach the History subjects in online & 2.14 & 4.75 & Disagreed \\
\hline 10 & $\begin{array}{l}\text { The students in my school do not have } \\
\text { adequate learning devices, such as laptops, } \\
\text { tablets, and smartphones devices to access } \\
\text { the internet and view the online materials. }\end{array}$ & 3.23 & 7.18 & Agreed \\
\hline 11 & $\begin{array}{l}\text { The shortness of the available time to solve } \\
\text { the online tests by my student affected their } \\
\text { performance. }\end{array}$ & 3.39 & 7.53 & Agreed \\
\hline
\end{tabular}

Cut off point: $X=2.5$ and above $=$ Agreed, less than 2.5 = Disagreed

Source: Field survey, 2021 
The remarks above were based on the cutoff point on the four Likert scale. Table 8 above reveals that the respondents (Historyteachers) indicated that factors such as cost of internet services, laptops, android phone, network/internet affected them from imparting the necessary knowledge into their students, therefore hindering student's learning on a large extent in Senior secondary schools in Ado Odo/Ota Local Government Area of Lagos State, except item 8 and 9, indicating that there is not always internet failure within the study area and the opinion of respondents on how hard to teach History subject online did not receive majority support of the respondents. This implies that the COVID-19 had immediate effect on student's learning.

\section{Research Question 2}

What are the innovations that are aiding teaching effectiveness of History teachers during the COVID-19 pandemic?

The research question was answered using the data presented in Table 8.

Table 8

\begin{tabular}{|c|c|c|c|c|}
\hline $\mathrm{S} / \mathrm{N}$ & $\begin{array}{l}\text { Mean ratings of respondents on the innovations } \\
\text { that are aiding teaching effectiveness of History } \\
\text { teachers during the COVID-19 pandemic }\end{array}$ & $\begin{array}{l}\quad \mathrm{X} \\
\text { Mean of } \\
\text { History } \\
\text { Teachers }\end{array}$ & $\begin{array}{l}\text { S D } \\
\text { Standard } \\
\text { Deviation }\end{array}$ & Remarks \\
\hline 12 & $\begin{array}{l}\text { Informing students of daily news related to COVID- } \\
\text { 19, current events or relevant college updates } \\
\text { using social media, like Twitter or Instagram, } \\
\text { facebooketc }\end{array}$ & 2.92 & 6.48 & Agreed \\
\hline 13 & $\begin{array}{l}\text { Availability of training opportunities using newly } \\
\text { innovatededucational technological tools among } \\
\text { teachers in my school motivates them to be } \\
\text { effective }\end{array}$ & 3.23 & 7.18 & Agreed \\
\hline 14 & $\begin{array}{l}\text { Making short recordings instead of typed } \\
\text { messages. Letting students see my face and hear } \\
\text { my voice can be reassuring for students in an } \\
\text { unsettling time. }\end{array}$ & 2.66 & 5.91 & Agreed \\
\hline 15 & $\begin{array}{l}\text { Utilizing the learning management system's (LMS) } \\
\text { messaging or announcement tools to remind my } \\
\text { students of assignments or upcoming due dates. }\end{array}$ & 2.61 & 5.79 & Agreed \\
\hline 16 & $\begin{array}{l}\text { Reminding my students of my availability. } \\
\text { Specifically, letting them know when they should } \\
\text { expect to hear back from me usually within } 24-48 \\
\text { hours using social media platform is a good } \\
\text { innovation for teaching effectiveness. }\end{array}$ & 3.29 & 7.29 & Agreed \\
\hline
\end{tabular}

Cut off point: $X=2.5$ and above=Agreed, less than $2.5=$ disagreed

Source: Field survey, 2021

Table 8 above showed that the Historyteachers agreed with all the items on innovations that aided teaching effectiveness of History teachers during COVID-19 pandemic as mean value is above 2.5 for items. This signifies that new technological applicable innovations aided teaching effectiveness of History teachers during COVID-19 pandemic in senior secondary schools in Ado Odo/Ota Local Government Area of Ogun State. 
Research Question 3

Is there any significantimpact of COVID-19 on teaching effectiveness of History teachers in the selected secondary schools in Ado Odo/Ota Local Government Area of Ogun State?

The research question was answered using the data presented in Table 9.

Table 9

\begin{tabular}{|c|c|c|c|c|}
\hline $\mathrm{S} / \mathrm{N}$ & $\begin{array}{l}\text { Mean ratings of respondents on significant } \\
\text { effect of COVID-19 on teaching } \\
\text { effectiveness of History teachers in the } \\
\text { selected secondary schools in Ado } \\
\text { Odo/Ota Local Government Area of Ogun } \\
\text { State. }\end{array}$ & $\begin{array}{l}\text { X } \\
\text { Mean of } \\
\text { HistoryTeachers }\end{array}$ & $\begin{array}{l}\text { SD } \\
\text { Standard } \\
\text { Deviation }\end{array}$ & Remarks \\
\hline 17 & $\begin{array}{l}\text { There is improvement in online academic } \\
\text { performance of my students in History } \\
\text { class }\end{array}$ & 3.29 & 7.29 & Agreed \\
\hline 18 & $\begin{array}{l}\text { Students can learn from their homes or } \\
\text { anywhere if they have internet access. }\end{array}$ & 3.02 & 6.72 & Agreed \\
\hline 19 & Support materials can be easily uploaded. & 3.18 & 7.02 & Agreed \\
\hline 20 & $\begin{array}{l}\text { Attracting students and having fun doing } \\
\text { activities. }\end{array}$ & 2.24 & 4.98 & Disagreed \\
\hline 21 & $\begin{array}{l}\text { Strengthening teacher-student } \\
\text { relationships hence enhancing teaching } \\
\text { effectiveness of History teachers. }\end{array}$ & 2.55 & 5.67 & Agreed \\
\hline
\end{tabular}

Cut off point: $X=2.5$ and above=Agreed, less than $2.5=$ disagreed

Source: Field survey, 2021

The items on table 10 showed the there is significant effect of COVID-19 on teaching effectiveness of History teachers in senior secondary schools in Ado Odo/Ota Local Government Area of Ogun State. The respondents agreed with all the items except item 20, on which they disagreed. This indicates the respondents believe that students do not see online learning as having fun and interesting. The findings however revealed that COVID-19 pandemic has significant effect (both positive and negative) on teaching effectiveness of History teachers in the selected senior secondary schools within the study area. 


\section{Research Question 4}

What are the implications of learning- from home on teaching effectiveness of History teachers in some selected secondary schools in Ado Odo/Ota Local Government Area of Ogun State?

The research question was answered using the data presented in Table 10.

Table 10

\begin{tabular}{|c|c|c|c|c|}
\hline $\mathrm{S} / \mathrm{N}$ & $\begin{array}{l}\text { Implications of learning- from home on teaching } \\
\text { effectiveness of History teachers }\end{array}$ & \begin{tabular}{l}
\multicolumn{1}{c}{$\mathrm{X}$} \\
Mean of \\
History \\
Teachers
\end{tabular} & $\begin{array}{l}\text { SD } \\
\text { Standard } \\
\text { Deviation }\end{array}$ & Remarks \\
\hline 22 & Learning from home is easy and flexible & 2.14 & 4.75 & Disagreed \\
\hline 23 & $\begin{array}{l}\text { Teachers learn new educational technological tools } \\
\text { and acquire new skills to teach online. }\end{array}$ & 3.13 & 6.95 & Agreed \\
\hline 24 & $\begin{array}{l}\text { Some History teachers have difficulty in performing } \\
\text { assessments and correcting students' mistakes } \\
\text { online. }\end{array}$ & 2.71 & 6.02 & Agreed \\
\hline 25 & $\begin{array}{l}\text { There is difficulty of gathering all students for } \\
\text { onlinelearning at the same time. }\end{array}$ & 2.87 & 6.37 & Agreed \\
\hline 26 & $\begin{array}{l}\text { Some students focus more on video and animation } \\
\text { than on content }\end{array}$ & 2.50 & 5.56 & Agreed \\
\hline
\end{tabular}

Cut off point: 2.5 and above $=$ Agreed, less than $2.5=$ Disagreed

Source: Field survey, 2021

The results above revealed that HistoryTeachers agreed with all other items except item 22 disagreeing that learning from home is flexible and easy. This shows that implications of learning from home on teaching effectiveness of History teachers has more positive impacts than its negative impacts as it involves teacher and students participation. It is learner-centred and also boosts inter-personal relationship between teacher and students. This is because team work can only be attained through interpersonal relations. It therefore promotes team spirit and attainment of effectiveness.

\section{FINDINGS OF THE STUDY}

The survey generated many ideas and much good advice. Below are eight particularly noteworthy findings regarding education in COVID-19 pandemic period:

1. Lack of access to technology is considered to be the biggest barrier for learning during the current pandemic together with school closures in Nigeria.

2. Researcher submits that learners in rural communities are those most likely to be disadvantaged as a result. The most cited limitation is the lack of availability and affordability of internet connectivity.

3. Secondary education is considered to be most likely to be disadvantagedby the crisis and least likely to be able to access the technologies required for learning.

4. Online learning is considered to be the most important and appropriate for teaching students in secondary schools.

5. The current COVID-19 pandemic will lead to more widespread useof technology in education in the future. However, this will lead to significantchallenges for the most marginalised and may increase inequality.

6. There is significant impact of COVID-19 pandemic on teaching effectiveness of History teachers. 


\section{SUMMARY}

Whether it is believed or not, the presence of the COVID-19 pandemic has opened the eyes of Historyteachers to learn and master new technological tools for the purpose of e-learning. Previously, a variety of supportive training initiatives had been implemented at various levels both by government and school management, it would still not have changed the landscape of teacher thinking. However, in the desperate need for teachers to usee-learning platforms to deliver their teaching, teachers have proven that they can actually apply latest technologies to teach for effective teaching. But things like teaching effectiveness still needs to be given priority in onlinelearning sessions.

\section{CONCLUSION}

This study showed that COVID-19 pandemic has significant effect on the teaching effectiveness of History teachers in either of the two sides, it ensures that History teachers had to equip themselves with skills needed for online learning as well as inculcating new technological tools as instructional materials for effective teaching, while the students had to brace up for the challenges posed by the COVID-19 pandemic and learning online in their homes with little or no supervision making use new technological tools like laptops, phones, educational software like Zoom, Google meet, Google classroom etc in order to learn from home.

Implicitly, online education helps to keep the students up and running with an opportunity for self-study. Students think that it is difficult to fulfil the Historycompetencies considering its practical inclination, voluminous in content delivery and abstract in some concepts only with online education system.

\section{RECOMMENDATIONS}

Based on the findings on the study, some recommendations were made as follows:

1. Online education can be improved by making it more interactive, showing more Historicalprocedures in real situations, giving concise information, and providing 3D virtual tools to mimic the real situation.

2. School administrators need to constantly monitor and make an improvement to assurestakeholders that online learning is the future of education.

3. Relevant government agencies should ensure that national curriculum is adapted for the future in response to the current crisis, to enable more effective teaching on elearning

4. Teachers and learners need training on ICTs and e-learning facilities as to how they can be used to support learning. Both in-service teachers and the student teachers in educational institutions should be well trained in blended teaching and learning method.

5. The government can provide supports such as solar-powered educational devices, preloaded with offline academic resources, to students in disadvantaged and vulnerable communities to alleviate the negative impact of the pandemic on education and improve teaching effectiveness.

\section{References}

1. Anthony, S.J. (2017). Global patterns in coronavirus diversity. Virus evolution. 2017;3(1). 
2. Bennell, P. \& Mukyanuzi, F. (2005). Is there any teacher motivation crisis in Tanzania? Unpublished manuscript. Retrieved from: http://bit.ly/1SmN9D4

3. Bernard J.M., Coulibaly B.S., \& Winthrop R., (June 4, 2020) Education is crucial to Africa's Covid-19 Response OP-ED Brookings. Retrieved from https://www.brookings.edu/opinions/education-is-crucial-to-africas-covid-19response/

4. Butterfield D.A. Oxidative stress in neurodegenerative disorders. Antioxid. Redox. Signal. 2006;8:1971-1973. doi: 10.1089/ars.2006.8.1971.

5. Chin, T.D (2020). Morbidity and mortality characteristics of Asian strain influenza. Public health reports. 2020;75(2),149

6. Cucinotta D and Vanelli M. (2020). WHO declares COVID-19 a pandemic. Actabiomedica: Atenei Parmensis. 2020;91(1): 157-160.

7. Hammond, L.D. (2010). Evaluating Teacher Effectiveness. How Teacher Performance Assessments Can Measure and Improve Teaching. Retrieved from https://scale.stanford.edu/system/files/teacher_effectiveness.pdf http://www.findglocal.com/NG/Ojo/163598-10

8. Hui D. S. (2020). The continuing epidemic threat of novel coronaviruses to global healththe Latest novel coronavirus outbreak in Wuhan, China. International Journal of Infectious Diseases.2020;91:264-266.

9. Ko, J., Summons, P., \& Bakkum, L. (2013). Effective Teaching: A Review of Research and Evidence. Retrieved November 28, 2014 from http://cdn.cfbt.com/ /media/cfbtcorporate/files/research/2013/r-effectiveteaching- 2013.pdf

10. Landry, M.D. (2020). The novel coronavirus (COVID-19): making a connection between infectious disease outbreaks and rehabilitation. University of Toronto Press; 2020.

11. Maclean, R. and Dahir, A.L. (2020). Nigeria Responds to First Coronavirus Case in SubSaharan Africa. The New York Times. Retrieved. 2020;10.

12. Marra M. A. (2003). The genome sequence of the SARS-associated coronavirus. Science. 2003;300(5624):1399-1404

13. Munster, V. J., Koopmans, M., van Doremalen, N., Van Riel, D., and De Wit, E. (2020). A novel coronavirus emerging in China - key questions for impact assessment. N. Engl. J. Med. 382, 692-694. doi: 10.1056/NEJMp2000929

14. Obiakor, T., \& Adeniran, A. (2020). COVID-19: Impending situation threatens to deepen Nigeria's education crisis. Centre for the Study of the Economies of Africa (CSEA).

15. UNESCO Report (2020). 290 Million students out of school due to COVID-19: UNESCO releases first global numbers and mobilizes response. UNESCO; 2020c.

16. UNESCO (2020). National learning platforms and tools. Retrieved from https://en.unesco.org/covid19/educationresponse/nationalresponses

17. UNICEF (2020). Key messages and actions for COVID-19 prevention and control in Schools. World Health Organization. Available at: $<$ https://www.who.int/docs/defaultsource/coronaviruse/key-messages-andactionsfor-covid-19-prevention-and-control-inschools-march2020.pdf?sfvrsn=baf81d52_4>

18. World Health Organisation (2020). WHO announces COVID-19 outbreak a pandemic. (2020). Available online 
at: https://www.euro.who.int/en/health-topics/health-emergencies/coronaviruscovid-19/news/news/2020/3/who-announces-covid-19-outbreak-a-

pandemic (accessed August 25, 2020).

19. Zhu, N, Zhang, D, Wang, W, Li, X. Yang, B and Song, J, (2020). A novel coronavirus from patients with pneumonia in China, 2019. N Engl J Med. (2020) 382:727-33. doi: 10.1056/NEJMoa2001017 